\title{
We Have Been Visited: Divine Encounter through the Lukan Benedictus (Luke 1:68-79)
}

\author{
DAVID SEAL \\ Cornerstone University \\ david.seal@cornerstone.edu \\ ORCID: 0000-0003-4048-2086
}

\begin{abstract}
Recent discussions of the Benedictus have focused on its function in LukeActs. However, little if no attention has been given to the persuasive force of the passage and how it may have functioned to create a divine encounter for the implied audience. This study will address this gap. Following a brief survey of Luke's purpose and a discussion of the nature of prophecy, I will argue, first, that divine revelation was often cast in poetic form. Second, I will describe the poetic features of the Benedictus, emphasizing its divine nature. Third, I will explain the ancient perception that deities had a superior ability to name persons, places, and objects. I will follow this discussion with a listing of the divinely authored names in the Benedictus. Fourth, I will contend that the Old Testament vocabulary and the tone of confidence in Zechariah's prophecy further enhances its divine nature. Finally, considering the above, I will explain how a skilled lector reading the prophecy to Luke's original audience may have allowed them to experience something of the aural presence of God.
\end{abstract}

KeYwords: Benedictus; Divine Encounter; Luke, Gospel of; Poetry; Prophecy

Recent discussions of the Benedictus ${ }^{1}$ have focused on its function in LukeActs. ${ }^{2}$ However, little if no attention has been given to the persuasive force of the passage and how it may have functioned to create a divine encounter for the implied audience. ${ }^{3}$ Given that Zechariah's message was a Spirit endowed

1 The first word in Latin of Zachariah's prophecy in Luke 1:68-79 and thus the title of the oracle.

2 E.g. Stephen Farris (The Hymns of Luke's Infancy Narratives. Their Origin, Meaning and Significance [JSNTSup 9; Sheffield: Bloomsbury 1985] 151-160) focuses on the motifs of promise and fulfillment, and the restoration of Israel in the Benedictus and the other infancy hymns. Allan J. McNicol ("Rebuilding the House of David: The Function of the Benedictus in Luke-Acts," ResQ 40 [1998] 25-38) argues that the function of certain statements of the Benedictus, especially the claim of the coming restoration of the house of David, reveals that the glory of Israel would not rest in a physical house (the temple). Instead, the restoration of Israel would be fulfilled in the communal life of the church in Jerusalem. Joseph A. Fitzmyer (The Gospel according to Luke I-IX. Introduction, Translation, and Notes [AB 28; New Haven, CT - London: Yale University Press 2008] 378-379) states, in part, the canticle serves to enhance the connection of John with God's chosen people and to explain the special role he has in Israel's destiny. However, he says the main point of the canticle is an affirmation of the messianic role of Jesus. For an alternative function of the Benedictus see Richard J. Dillon ("The Benedictus in Micro- and Macrocontext," CBQ 68 [2006] 457-480).

3 The audience Luke is attempting to persuade. 
prophecy (Luke 1:67) - a word from God to humanity - this essay will demonstrate how Luke crafts the message of the Benedictus as God's voice, thereby persuading his recipients to trust what is spoken and remain faithful to their confession regardless of the pressures to do otherwise.

Following a brief survey of Luke's purpose and a discussion of the nature of prophecy, I will argue, first, that divine revelation was often cast in poetic form. Second, I will describe the poetic features of the Benedictus, emphasizing its divine nature. Third, I will explain the ancient perception that deities had a superior ability to name persons, places, and objects. I will follow this discussion with a listing of the divinely authored names in the Benedictus. Fourth, I will contend that the Old Testament vocabulary and the tone of confidence in Zechariah's prophecy further enhances its divine nature. Finally, considering the above, I will explain how a skilled lector reading the prophecy to Luke's original audience may have allowed them to experience something of the aural presence of God.

\section{Luke's Purpose}

Several scholars contend that Luke had written his Gospel and Acts for a Gentile Christian audience, or at least one that was predominantly Gentile Christian. ${ }^{4}$ This is particularly true for Gentiles who had been attracted to Judaism, the God of Israel, and the worship of the synagogue, and are now confronted with the ramifications of the coming of Jesus and the establishment of the Christian faith. These Gentile God-fearers were also likely being confronted by Jews who considered Christianity to be a dangerous perversion of their Jewish heritage, and who were urging them to remain a follower of traditional Judaism, rejecting the claims of the Christian faith. ${ }^{5}$ Framing Zechariah's words as direct divine revelation, perhaps even perceived by the audience as an aural encounter with God, Luke is persuading these Gentile God-fearers that Christianity is being offered to the non-Jew as the completion and fulfillment of the Judaism they have been following. While clearly written for Gentile readers, Luke and Acts also has several Jewish elements (e.g. use of the Old Testament and reference to Jewish messianic ideas), thereby appealing to and persuading a Jewish audience as well.

4 E.g., Fitzmyer, The Gospel according to Luke, 57-58; J. Nolland Luke 1:1-9:20 (WBC 35A; Dallas, TX: Word 1989) xxxii; N. Geldenhuys, Commentary on the Gospel of Luke. The English Text with Introduction, Exposition and Notes (NICNT; Grand Rapids, MI: Eerdmans 1952) 41.

5 Nolland, Luke 1:1-9:20, xxxii. 


\section{Prophecy and Spirit Filling: Indicators of a Divine Message}

According to Luke 1:67, Zechariah is to commence speaking a prophecy

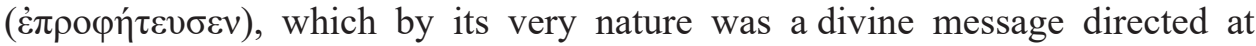
a human audience (e.g. Jer 1:9; Isa 51:16). ${ }^{6}$ The text reads "Then his father Zechariah was filled with the Holy Spirit and spoke this prophecy..." It was believed that a prophet of God in some way joined the divine assembly, overhearing the discussion, learning about the divine plans, which he then was to proclaim to the proper recipients (e.g. $1 \mathrm{Kgs} 22: 19$; Isa 6; Amos 3:6-7). ${ }^{8}$ This is evident in Yahweh's rhetorical question concerning false prophets: "For who has stood in the council of the Lord so as to see and to hear his word? Who has given heed to his word so as to proclaim it?" (Jer 23:18).

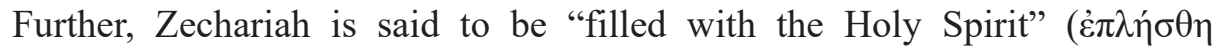

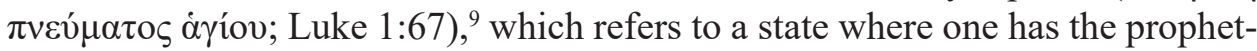
ic presence of God, manifested in the words that are to be spoken (e.g. Hos 9:7; Mic 3:8; Wis 7:22, 25; Sir 39:6). ${ }^{10}$ For Luke, when a person was "filled with the Spirit" they had divinely given ability to say exactly what God wanted said (e.g. Acts 2:4; 4:31; 9:17, 20-22; 13:9, 52 [cf. Acts 14:1]).

The Greek poet Hesiod related his encounter with the Muses, who influenced his speech in a manner similar to how the holy Spirit functioned in the Jewish

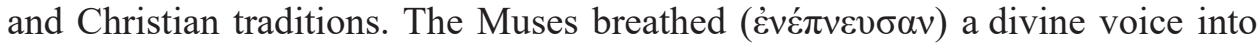
Hesiod (Hesiod, Theog. 31). Philo described his own experience of inspiration as one who was empty of ideas prior to any divine initiative, but once he was in a state of divine possession became $\pi \lambda \eta \dot{\rho \eta \varsigma ~(f u l l) ~ o f ~ l a n g u a g e ~ a n d ~ i d e a s ~(P h i l o, ~}$ Migr. 35). When the Spirit was present in a person, it could manifest itself in poetry, prophecy, visions, ecstasy, and glossolalia. Thus, prior to even hearing the divine message, we are informed that Spirit inspired Zechariah is to be proclaiming a prophetic word from God.

Zechariah begins his oracle saying, "Blessed be the Lord, the God of Israel"

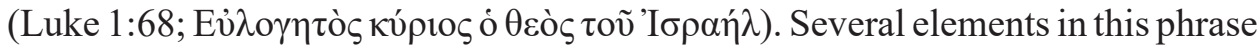

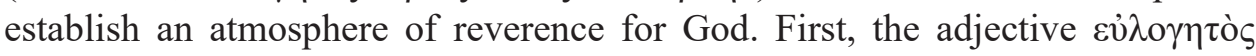

6 Warren Carter ("Zechariah and the Benedictus (Luke 1:68-79): Practicing What He Preaches,"

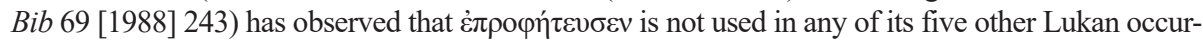
rences to designate words directed towards God but instead words directed to a human audience.

$7 \quad$ All biblical quotations are from the NRSV unless otherwise noted.

8 J. Ben-Dov, "Language, Prayer and Prophecy: 1 Enoch, the Dead Sea Scrolls and 1 Corinthians," Ancient Jewish Prayers and Emotions: Emotions associated with Jewish Prayer in and around the Second Temple Period, (eds. S.C. Reif - R. Egger-Wenzel) (DCLS 26; Berlin: De Gruyter 2015) 241.

9 In the aorist tense, $\dot{\varepsilon} \pi \lambda \dot{\sigma} \sigma \theta \eta$ (filled) can describe a momentary experience, but it can also refer to the beginning of a new state.

10 Fitzmyer, The Gospel according to Luke, 382. 
rendered "blessed" means "praised." "11 With the words "Blessed [Praised] be the Lord," Zechariah uses a common Jewish exclamation of blessing and praise that was practiced at meals, in the synagogue, and at festal occasions (cf. Tob 13:1 and Sg Three 29-68). The blessing formula, or berakhah comes from the He-

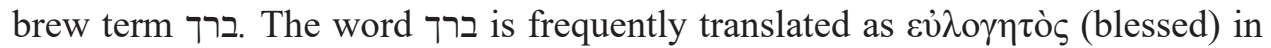
the Septuagint (e.g., Dan 3:28 [3:26 LXX]; Ps 31:21 [30:22 LXX]; 41:13 [40:14 LXX], Zech 11:5 LXX). In Hebrew ברך is a verb that literally means to fall on one's knees. ${ }^{12}$ Thus, in both word and posture, Zechariah sets a reverent tone for the extremely poetic oracle that follows.

\section{The Divine Nature of Poetry}

Texts recounting divine revelations have generally been highly and even exceptionally poetic texts. ${ }^{13}$ Poetry in the ancient world was considered the language of the gods. The oracles at Delphi, with the priestess of Apollo, as well as the sibyls at various sites in the ancient world like Cumae (near Naples), delivered their prophecies typically in hexameter verses. ${ }^{14}$ The Muses gave poets the ability to craft beautiful songs and poems (e.g. Homer, Od. 8.481; Hesiod, Theog. 22). ${ }^{15}$ In the Hellenistic and Roman periods, the Greeks widely accepted the divine inspiration of poetry (e.g. Homer, Od. 8.44, 64, 488, 498; 17.518; 22.347). ${ }^{16}$ Socrates stated that poets "don't do what they do from wisdom, but from some natural inspiration, like prophets and oracle mongers" (Plato, Apol. 22b8-c2) ${ }^{17}$ Again Socrates noted remarked about the poet, "For the god, as it seems to me, intended him to be a sign to us that we should not waver or doubt that these fine poems are not human or the work of men, but divine and the work of gods; and that the poets

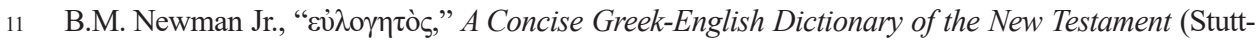
gart: Deutsche Bibelgesellschaft - United Bible Societies 1993) 76.

12 F. Brown - S.R. Driver - C.A. Briggs, "ברך," Enhanced Brown-Driver-Briggs Hebrew and English Lexicon (Oxford: Clarendon 1977) 1085.

13 K.M. Heffelfinger, "More than Mere Ornamentation," PIBA 36 (2013) 45.

14 W. Franke, "At the Creative Source of the Arts: Poetry as Prophecy in a Negative Theological Key," Prophetic Witness and the Reimagining of the World. Poetry, Theology and Philosophy in DialoguePower of the Word V (eds. M.S. Burrows - H. Davies - J. von Zitzewitz) (Routledge Studies in Religion; New York: Routledge 2021) 30-31.

15 P. Murray, "Poetic Inspiration," Companion to Ancient Aesthetics (eds. P. Destrée - P. Murray) (Chichester, England: Wiley \& Sons 2015) 159.

16 Christopher D. Stanley ("Paul and Homer: Greco-Roman Citation Practice in the First Century," NovT 32 [1990] 51-52) argues that Homer was widely regarded as genuine divine truth in the first century Greco-Roman world.

17 Plato, Euthyphro. Apology. Crito. Phaedo (trans. E. Jones - W. Preddy) (LCL 36; Cambridge, MA: Harvard University Press 2017) 125. 
are merely the interpreters of the gods, according as each is possessed by one of the heavenly powers" (Plato, Ion 534e-535a). ${ }^{18}$

The biblical prophets also composed their divine messages in a poetic and musical style (e.g. Isa 5; Ezek 33:32). Some of the Psalms, which are poetic by nature, contain oracles where God is addressing Israel, or the nations, or pagan deities (e.g. Ps 81:6-16, 82:2-7). As Robert Alter has said, poetry is our best human model of complex and rich communication, being "solemn, weighty, and forceful."19 Zechariah's poetic oracle suggests that both his audience and the Lukan one as well believed they were hearing more than human words but a divine declaration, thereby underscoring the prophecy's authority and trustworthiness.

Because of the danger associated with being in the divine presence (e.g. Gen 16:13, 32:30; Exod 33:18-20; Judg 6:22-23; 13:22), it might be argued that poetic language served as sort of a literary garb, clothing the divine voice in a "veil" to protect the listener from the searing vocal presence of God. ${ }^{20}$ The aural presence of God was considered a threat to mortals (Exod 20:18-19; Deut 5:22-27). For example, when Elijah heard the voice of God, having been struck dumb, he wrapped his face in his mantle (1 Kgs 19:11-13).

Consequently, it is appropriate that divine speech should be represented as poetry. By setting Zechariah's oracle in poetry, Luke was "putting divine speech in special divine speech quotation marks." ${ }^{21}$ In the next section we will examine the numerous poetic features of the Benedictus, emphasizing the divine character of the oracle.

\section{Poetic Features in the Benedictus}

Poetry may best be defined through the volume of the various poetic conventions or literary devices present in a text — devices such as parallelism, metaphoric language, and various rhetorical figures of speech. If a passage contains a substantial amount of these devices, it can likely be labeled as poetry. A prose text is characterized by the presence of far less of these features.

There are several poetic features that we can identify in Zechariah's prophetic text. First, the Benedictus displays a neat poetic arrangement. It is framed by

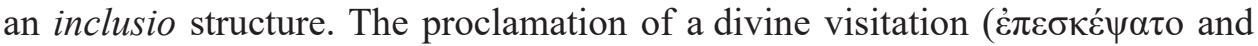

18 Plato, Statesman. Philebus. Ion (trans. H.N. Fowler - W.R.M. Lamb) (LCL 164; Cambridge, MA: Harvard University Press 1925) 425. See also Homer, Od. 8.488.

19 R. Alter, The Art of Biblical Poetry (New York: Basic Books 2011) 147.

20 S.A. Geller, "Were the Prophets Poets?" Proof 3 (1983) 212.

21 Katie M. Heffelfinger ("More than Mere Ornamentation," 38) makes this statement regarding the prophetic oracles of the Old Testament. 
$\dot{\varepsilon} \pi 1 \sigma \kappa \varepsilon \dot{\psi \varepsilon} \tau \alpha \imath$ ) dominates both the beginning and ending (Luke 1:68, 78), emphasizing the theme of the oracle-God's benevolent, salvific intervention on behalf of humanity.

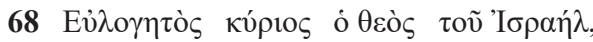

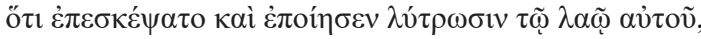

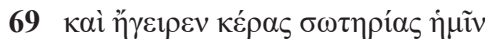

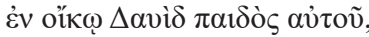

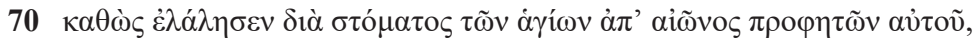

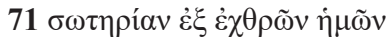

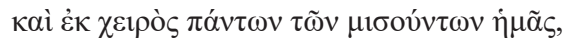

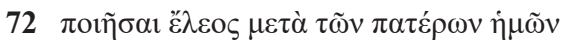

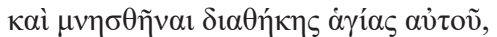

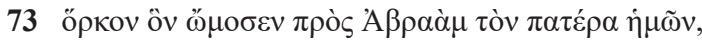

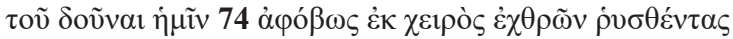

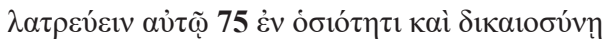

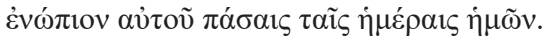

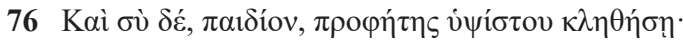

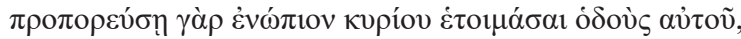

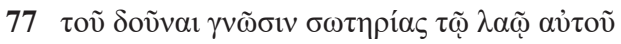
$\dot{\varepsilon} v \dot{\alpha} \varphi \varepsilon \dot{\varepsilon} \sigma \varepsilon i \dot{\alpha} \mu \alpha \rho \tau \imath \tilde{\omega} v \alpha \hat{\tau} \tau \tilde{\omega} v$,

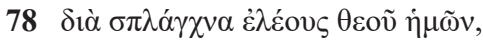

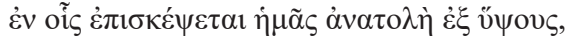

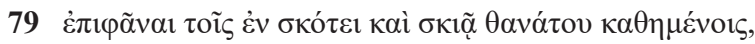

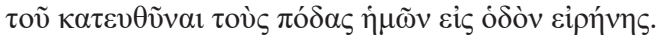

68 Blessed be the Lord, the God of Israel, because he has visited to help and has redeemed his people,

69 and has raised up a horn of salvation for us in the house of his servant David,

70 just as he spoke through the mouth of his holy prophets from earliest times71 salvation from our enemies and from the hand of all those who hate us,

72 to show mercy to our fathers and to remember his holy covenant,

73 the oath that he swore to Abraham our father, to grant us $\mathbf{7 4}$ that we, being rescued from the hand of our enemies, could serve him without fear $\mathbf{7 5}$ in holiness and righteousness before him all our days.

76 And so you, child, will be called the prophet of the Most High, for you will go on before the Lord to prepare his ways, 
77 to give knowledge of salvation to his people

by the forgiveness of their sins,

78 because of the merciful compassion of our God

by which the dawn will visit to help us from on high,

79 to give light to those who sit in darkness and in the shadow of death, to direct our feet into the way of peace. ${ }^{22}$

Second, the Benedictus is characterized by the basic building block of poetry - the couplet, which consists of two contiguous lines related to each other by form and by content. Most lines of the Benedictus can be considered couplets, including verses $68,69,71,72,76,77,78,79$, and perhaps, 74b-75. While parallelism, ${ }^{23}$ a distinctive feature of ancient Near Eastern poetry, does characterize some of these couplets (vv. 71, 72, 79), it is not present in all of them. However, repetition in the form of conduplicatio (Rhet. Her. 4.18.38) ${ }^{24}$ is apparent in the reuse of various key or thematic words in the poem. Since repetition of these words emphasizes certain themes and deepens their meaning by using them in several contexts, it has the poetic effect of parallelism. ${ }^{25}$ Key repeated words include the noun " $\sigma \omega \tau \eta \rho i ́ \alpha$ " in verse 69 that is restated in verse 71 ( $\sigma \omega \tau \eta \rho i \alpha v)$. The word "enemies" ( $\dot{\chi} \chi \rho \tilde{\omega} v)$ in verse 71 reappears in verse 73 . The term "hand" ( $\chi \varepsilon i \rho o ̀ \varsigma)$ appears in verses 71 and 74. "Father(s)" ( $\pi \alpha \tau \dot{\varepsilon} \rho \omega v / / \pi \alpha \tau \dot{\varepsilon} \rho \alpha)$ occurs in verse 72 and then again in verse 73. Finally, the noun "way" or "path" (ódov̀ // ódòv) is used in both verses 76 and $79 .{ }^{26}$ So, the loosely strung but linked clauses, with several repeating words create a pattern of "emphasis and enrichment," of key themes in the oracle. ${ }^{27}$

Finally, other poetic devices in the Benedictus include polyptoton (Rhet. Her. 4.21.29-4.23.32; Inst. 9.3.36-37), ${ }^{28}$ employed in the terms $\sigma \omega \tau \eta \rho i ́ \alpha v$

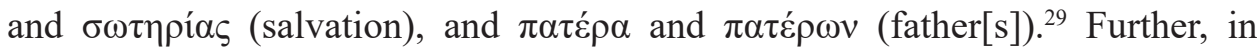

22 Lexham English Bible.

23 True parallelism, traditionally called "synonymous parallelism," is a twofold statement of a single idea or concept that employs near synonymous or related vocabulary in a symmetrical fashion. "Synthetic parallelism" is a structure in which the second line supplements the first. Antithetic parallelism is identified when parallel statements are placed in opposition to one another.

24 The figure in which there is a repetition of one or more words for the purpose of amplification or appeal to pity.

25 R.C. Tannehill, The Narrative Unity of Luke-Acts. A Literary Interpretation. I. The Gospel According to Luke (Minneapolis, MN: Fortress 1991) 33.

26 Tannehill, The Narrative Unity, I, 34.

27 Tannehill, The Narrative Unity, I, 33-34.

28 The figure in which the cases of the words are changed. It can be effective when recited out loud as the speaker stresses the repeated root.

29 H.E. Mendez, Canticles in Translation. The Treatment of Poetic Language in the Greek, Gothic, Classical Armenian, and Old Church Slavonic Gospels (Diss. The University of Georgia; Athens 2013) 64. 
verse $75 \mathrm{~b}$, homoeoptoton is utilized, where similar case endings in the phrase

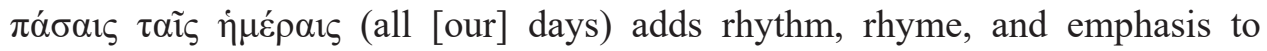
the length of time God's people can serve him without fear (Rhet Her. 4.20.28; Quintilian, Inst. 9.3.78-79). Setting Zechariah's oracle in poetry allowed Luke to present him as speaking in the persona of God, underscoring the reliability of the message and possibly increasing the sense of the vocal divine presence for the Lukan audience as they heard the words recited.

\section{The Divine Name-Giver}

Not only was poetry considered to be the language of the deities, but it was also believed that the gods' language was superior to humans. This was reflected in their ability to assign better sounding and more perfect names to a god, a person, or an object (Homer, Il. 1.403; 2.813; 14.291; 20.74).$^{30}$ Names assigned by a deity belonged to a higher, more poetic register. Socrates explained that names were originally designed by a "name-giver," if, who was not himself a god, was at least someone closer to gods than men, and therefore, had superior wisdom (Plato, Crat. 434a). The difference between the language of humanity and the language of the gods is that the latter uses meaningful names, which reflect the nature of the referent, while the former uses unclear ones (Plato, Crat. 391e). ${ }^{31}$ Divine language was believed to be more perfect than human vernacular because there was a logical relationship between form (the name) and meaning of a word, whereas in human language there is none..$^{32}$ For example, the god Hermes's name was given as "Eiremes" signifying one who was tricky, deceptive. Thus, the divine designation describes one who was contriving in his speech (Elpeiv

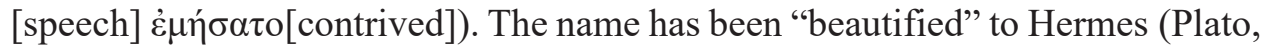
Cratylus 408a-b). ${ }^{33}$ Metaphors and other referential divine language are closer to perfection than human language because the material form of a word matches the meaning of the word. ${ }^{34}$

30 D.L. Gera, Ancient Greek Ideas on Speech, Language, and Civilization (New York: Oxford University Press 2003) 53.

31 As noted by Claire Le Feuvre ("Language of Gods, Pythian Apollo and Plato's Cratylus," When Gods Speak to Men. Divine Speech according to Textual Sources in the Ancient Mediterranean Basin [eds. S. Anthonioz - A. Mouton - D. Petit] [OBO 289; Leuven: Peeters 2019] 98-99).

32 Le Feuvre, "Language of Gods," 88.

33 Plato. Cratylus. Parmenides. Greater Hippias. Lesser Hippias (trans. H.N. Fowler) (LCL 167; Cambridge, MA: Harvard University Press 1926) 87. For other examples of names assigned by the gods see Le Feuvre ("Language of Gods").

34 Le Feuvre, "Language of Gods," 98. See also Homeric Hymn to Aphrodite 5.196-201. 
Divine naming or re-naming of persons was also characteristic of God in the Bible. God changed Abraham's name from Abram ("exalted father") to Abraham ("father of a multitude"; [Gen 17:5]). God changed Sarai's name to Sarah (Gen 17:15). He named Abraham's son Isaac ("he laughs") because of the laughter of his parents at the possibility of a birth so late in their life (Gen 17:17-19). In Isaiah 8:1-4, God names Isaiah's son Maher-shalal-hash-baz, which means "quick to the plunder, swift to the spoil." As a messenger of God, Gabriel names Mary's son Jesus, "for he will save his people from their sins" (Matt 1:21; Luke 1:31). ${ }^{35}$

Zechariah's poetic oracle contains names in the form of metaphors and other referential language, exhibiting the more precise divine vocabulary discussed above. As will be demonstrated, it reveals more of the true nature of the referent, who in the Benedictus, is God or the Messiah. For example, in verse 69, "horn of salvation" ( $\varepsilon \dot{p} \rho \alpha \varsigma \sigma \omega \tau \eta \rho i ́ \alpha)$ is a metaphor for describing divine strength or power where the imagery is that of the erect horns of a powerful animal. Here it serves as a designation for the Messiah. Another descriptive term,

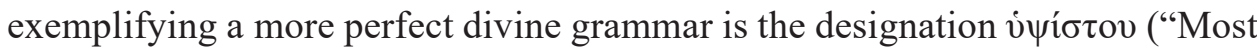
High"), which is the title applied to Yahweh as an explicit assertion of his distinctiveness above all other gods (e.g. Ps 97:9; 83:18). It is also a title associated with his kingship (Ps 47:2). It deliberately stresses the transcendence of God

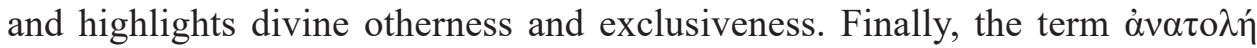
(dawn) can refer to the upward movement of celestial bodies, the position of the rising sun in the east, or a change from darkness to light (Luke 1:78). ${ }^{36}$ Here it is employed as a title, "the one arising," or "the dawn," where it functions as a messianic metaphor and denotes the appearing of the Messiah as a divine

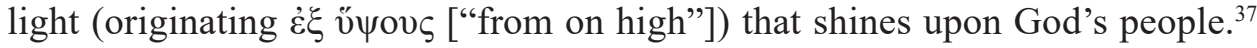
All these functional designations suggest a divine name-giver, and, in addition to the sophisticated language of the poetic prophecy, it emphasizes to those in earshot of Zechariah, and to the original Lukan audience that they are hearing a trustworthy word from God.

35 See also Gen 16:11; 1 Chron 22:9.

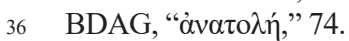

37 In the Septuagint, $\dot{\alpha} v \alpha \tau 0 \lambda \eta$ can also translate צמח and refer to a "branch," or "shoot," which is also one of the stereotypical messianic titles (e.g. Jer 23:5; Zech 3:8; 6:12). It is noteworthy that in Zecha-

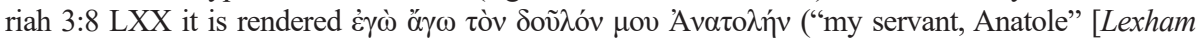
English Septuagint]). In Hebrew it is rendered את־עבדי צמה ("my servant the Branch"). 


\section{Divine Vocabulary from the Old Testament}

In addition to the presence of the more precise divinely given names, the Benedictus contains a significant amount of language and vocabulary from the Old Testament, especially the Psalms and prophetic books of Isaiah. Most scholars note numerous instances of vocabulary from the Old Testament present in the Benedictus, but agree at least on the following. ${ }^{38}$ In verse 71 , the terminology "hand of the foe or enemy" is similar to Psalm 106:10. In verse 72, to "remember his holy covenant" is an echo from Psalm 105:8 and 106:45. Verse 76 "for you will go on before the Lord to prepare his ways" echoes Malachi 3:1 and Isaiah 40:3. Finally, verse 78 alludes to Isaiah 9:2 and verse 79 alludes to Isaiah 59:8. It is noteworthy that the first half of Zechariah's words come from the Psalms, (remembering that according to Luke [Luke 24:44] the Psalms were prophetic words), ${ }^{39}$ while the second half mimics the prophetic texts. Luke has formulated Zechariah's words from sources that were deemed authoritative and sacred by his audience. The stylistic use of Old Testament language reflects the author's attempt to reproduce Hebrew praise and prophecy. Pseudo-Longinus felt that by mimicking the style of past authorities it endowed a speaker with inspiration and expressiveness as if his words were an emanation from a holy tongue similar to the Pythian priestess who after having been possessed with the divine power was inspired to utter oracles ([Subl. $] 13.2-3 ; 14.1)$. Luke demonstrates this practice by borrowing specific expressions and motifs from the former prophets.

While none of the Benedictus contains any direct quotations from the Old Testament, Anna Wierzbicka's "theatrical" theory of quotations is applicable. ${ }^{40}$ The theory posits that in using quotes from others an author is dramatizing the words of an earlier speaker to a later audience, and thereby temporarily assuming the role of that speaker. Thus, in employing stylistic language from the Old Testament, Zechariah is assuming the role of Israel's respected prophets and for a moment takes on the persona of the Psalmist, Malachi, and Isaiah, who had delivered authoritative words from God in the past.

38 E.g. H. Ringgren, Luke's Use of the Old Testament," HTR 79 (1986) 232; C. Perelman - L. Olbrechts-Tyteca, The New Rhetoric. A Treatise on Argumentation (Notre Dame, IN: University of Notre Dame Press 1969; 1973) 177. While a bit overly zealous, Raymond Brown (The Birth of the Messiah. A Commentary on the Infancy Narratives in the Gospels of Matthew and Luke, 2 ed. (ABRL; New York: Doubleday 1993] 386-389) has shown how it is possible to parallel every line of the Benedictus to one or more texts from the Old Testament and/or the writings of Second Temple Judaism.

39 As noted by McNicol ("Rebuilding the House of David," 30).

40 A. Wierzbicka, "The Semantics of Direct and Indirect Discourse," Papers in Linguistics 1 (1974) 267-307, esp. 272. 


\section{Divine Tone and Emotions}

Hearing Zechariah's oracle as a divine encounter not only presents the words of God, but also the emotions that the voice both expresses and elicits. The emotions of this encounter are not incidental but are the heart of the experience of hearing the speaker's address. ${ }^{41}$ In addition to poetry as an emotionally charged form, expressions of supreme confidence in the Benedictus convey the power and majesty of God. The declarations that through John and Jesus, God would rescue his people from their enemies, give knowledge of salvation to them, give illumination for those dwelling in darkness and in the shadow of death, and direct them into the way of peace (Luke 1:71-79) are magnanimous promises of astounding feats, projecting extreme confidence and authority. For the Lukan audience, the poetic oracle presents the activities of a supremely confident and capable God who can be trusted.

\section{Delivery of the Divine Voice}

The Gospel of Luke was one of several texts that was likely read aloud as part of a Christian gathering for edification and instruction purposes (cf. 1 Thess 5:27, Col 4:16, 1 Tim 4:13; Rev 1:3). Societies where news and information are predominantly conveyed orally are called oral cultures. Oral cultures enjoy literature primarily through the ears rather than by reading silently with the eyes. Most people in the first-century Mediterranean world could not read according to modern standards of literacy. Scholars believe that the overall level of literacy in the first-century New Testament world was about twenty percent among men and a lower rate for women and individuals living in the provinces. ${ }^{42}$

41 Heffelfinger, "More than Mere Ornamentation," 52. See also K.M. Heffelfinger, I Am Large, I Contain Multitudes. Lyric Cohesion and Conflict in Second Isaiah (Leiden: Brill 2011).

42 G.S. Holland, "Paul and Performance," Paul in the Greco-Roman World. A Handbook (ed. J.P. Sampley) (London: Bloomsbury 2016) II, 242. There is some debate on the literacy level in the first century biblical world. In his extensive study of ancient literacy, William V. Harris (Ancient Literacy [Cambridge: Harvard University Press 1989] 267) concludes that the overall level of literacy in the first century ancient eastern Mediterranean world was below fifteen percent. Catherine Hezser (Jewish Literacy in Roman Palestine [TSAJ 81; Tübingen: Mohr Siebeck 2001] 496) believes that the literacy rate among Jewish individuals may have been as low as three percent, depending on how one understands and defines "literacy." Based on his study of first century communal reading events, Brian J. Wright (Communal Reading in the Time of Jesus. A Window into Early Christian Reading Practices [Minneapolis, MN: Fortress 2017]) contends that written texts were experienced broadly by people of various social and educational levels. This might suggest that the low percentages of literacy among the Roman and Jewish population in the first century was much higher. See also 
For the most part, reading was considered physical labor and carried little or no status. Pliny the Younger, who could read, spoke of hiring one of his slaves, who was a slightly better reader than himself, to publicly recite his poetry for him (Ep. 9.34). The congregations likely included both slaves and slave owners. Those slaves who were clerks may have been literate. Other literate groups included scribes, priests, Pharisees, Sadducees, and other religious teachers who provided the masses with access to the holy texts (e.g. Matt 12:3, 5; 19:4; $21: 16,42 ; 22: 31)$. Thus, it is possible that someone from the church community would have been able to read Luke's Gospel.

A public reading of a text likely involved some level of practice as opposed to a speaker delivering his speech, message, or story impromptu. Greek writing presented difficulties for the unprepared reader. Vocalization of ancient Greek texts required navigating through a "river of letters" since texts were written without any punctuation or gaps between words but were just a continuous sequence of capital letters. Thus, a speaker would need to be well acquainted with the work prior to reciting it before an audience, dedicating some time to regular practice (Plutarch, Dem. 8). ${ }^{43}$ To read aloud in public likely required a much higher degree of comprehension by the reader than it does today.

Additionally, to obtain the most convincing argument, lectors or readers might have borrowed some of the tactics of the professional speakers and adapted them for their public recitations. The techniques of the professional speaker set the standard for all kinds of public speech. This would involve the ability to correctly pronounce terms, clear vocal expression, and correct pronouncement of syllables. Because of the importance attributed to the voice, any fault or blemish was criticized by a relentless public (Lucian, Laps. 1; Plautus, Bacch. 432-434; Irenaeus, Haer. 3.7.1-2; Petronius, Satyricon 68). In addition, it would have been important for a speaker to be able to adapt his voice to bring out the character and meaning of the passage. Aristotle discussed how the voice should be adapted to express different emotions (Rhet. 3.1 passim). When Socrates asked Ion if he was aware that when he exhibits emotions in his performances that he generates the same feelings in his spectators, Ion replied that he was mindful of this influence he had on his audience (Plato, Ion 535b-e6). ${ }^{44}$ Antonius insisted that to move an audience, the orator must genuinely feel the emotions he wishes to arouse in them (Cicero, De Oratore 2.189-96). The ability to move an audience is an essential part of the orator's art.

S.E. Porter - A.W. Pitts, Fundamentals of New Testament Textual Criticism (Grand Rapids, MI: Eerdmans 2015) ch. 3.

43 As noted by Rex Winsbury (The Roman Book. Books, Publishing and Performance in Classical Rome [London: Duckworth 2009)] 113).

44 As noted by Penelope Murray ("Poetic Inspiration," 163). 
In the reading of Zechariah's prophecy, the lector was not simply giving the impression of the character of Zechariah, rather in performance the prophet reappears. A transformation occurs at the moment of performance. The lector is not himself and at the same time he is himself-co-existing as multiple personalities. The lector not only personified the human dimension when reading Luke aloud, but also the divine. In some ways when a lector read Zechariah's oracle to the original audience, he was inviting them into an encounter with the aural presence of God. While the divine word in the form of a poetic oracle conferred a message, they were also a means of an experience and encounter with the divine speaker. ${ }^{45}$ Poetry persuades, not through argument alone, but through encounter-encounter with the voice that speaks through the prophet.

Given that Zechariah's oracle was literally the voice of God, would the words have been vocalized any differently by the lector or reader? The gods do not talk like humans. Homeric gods and the God of Scripture sound different from mortals. They are greater than humans, and so it is only natural that their voices are louder. A god's shout sounds as loud as 9,000 or 10,000 warriors (Homer, Il. 5.859-61, 14.147-51), sending mortals into panic (e.g. Il.5.862-3, 15.320-1; Homer, Od. 24.48-9, 530). ${ }^{46}$ God spoke to the Israelites on the mountain with a voice that caused them great fear (Exod 20:18-19; Deut 5:22-27). In the Old Testament, terror of people experiencing the divine audible presence may be attributed to the volume of his voice, as God's speech is often characterized as "mighty," "powerful," "roaring," or "thunderous" (e.g., 1 Sam 7:10; 2 Sam 22:14; Ps 29:4; 46:6; Job 37:2; Jer 25:30; Amos 1:2). In Revelation, the one like the son of man is described as having a loud voice, imitating both the sound of many waters $(1: 15)$ and a trumpet (1:10). The voice from heaven (14:2) and from the heavenly throne (21:3) also broadcast loudly like many waters.

Did the lector raise his voice to reflect that God was speaking or articulate in a tone to lend credence to the confidence reflected in the oracle? There are inevitable limitations and a fair amount of speculation in attempting to determine the way a biblical passage was initially delivered. The original performances are lost, but it is important to note that in the ancient Mediterranean world, impersonation of a figure was a highly valued rhetorical device. Professional speakers employed impersonation to achieve a variety of purposes such as to display the inner thoughts of adversaries and to introduce conversations between themselves and others. ${ }^{47}$ Impersonation or prosopopoiia is the act of giving voice to a figure such as an opponent, a fictive representative of a people, an ancient nobleman raised

\footnotetext{
45 Heffelfinger, "More than Mere Ornamentation," 52.

46 As noted by John Heath (The Talking Greeks. Speech, Animals, and the Other in Homer, Aeschylus, and Plato [New York: Cambridge University Press 2005] 52).

47 R.F. Ward - D. Trobisch, Bringing the Word to Life. Engaging the New Testament through Performing It (Grand Rapids, MI: Eerdmans 2013) 15.
} 
from the dead, or even to bring down the gods from heaven in order to strengthen the argument of the author or speaker who employs the device. ${ }^{48}$ According to Quintilian, these impersonations can be used 1) to reveal an opponent's inner thoughts, 2) to introduce imaginary conversations, or 3) to supply an opportunity for the author to advise, to rebuke, to complain, to praise, or to mourn (Quintilian, Inst. 9.2.30-31). ${ }^{49}$ The speaker would take the character's fortune, social rank, and achievement into account, then communicate these elements by means of suitable gestures and vocal intonations. ${ }^{50} \mathrm{~A}$ skilled and prepared lector-reader, by utilizing an authoritative and confident tone, could present more fully that God was speaking when reciting Zechariah's oracles.

\section{Summary and Conclusion}

Through the divine language of poetry, divinely assigned titles, and Old Testament prophetic vocabulary, Zechariah's oracles present a confident and trustworthy message describing God's salvific visitation. Further, the oracle, fittingly spoken by a lector may have generated a second "divine visitation" for the Lukan audience upon experiencing the aural presence of God. Extravagant language such as that of the Benedictus can instill an attitude of awe or reverence to those listening, thereby persuading the Lukan audience to trust what is spoken and remain faithful to their confession regardless of the pressures to do otherwise.

\section{Bibliography}

Alter, R., The Art of Biblical Poetry (New York: Basic Books 2011).

Bauer, W. et al. (ed.), A Greek-English Lexicon of the New Testament and Other Early Christian Literature (Chicago, IL: University of Chicago Press 2010) (=BAGD).

Ben-Dov, J., "Language, Prayer and Prophecy: 1 Enoch, the Dead Sea Scrolls and 1 Corinthians," Ancient Jewish Prayers and Emotions. Emotions associated with Jewish Prayer in and around the Second Temple Period (eds. S.C. Reif - R. Egger-Wenzel) (Deuterocanonical and Cognate Literature Studies 26; Berlin: De Gruyter 2015) 239-258.

Brown, F. - Driver, S.R. - Briggs, C.A., Enhanced Brown-Driver-Briggs Hebrew and English Lexicon (Oxford: Clarendon 1977).

48 J.R. Dodson, The 'Powers' of Personification. Rhetorical Purpose in the 'Book of Wisdom' and the Letter to the Romans (BZNW 161; Berlin: De Gruyter 2008) 36.

49 As noted by Joseph R. Dodson, The 'Powers,' 36, 37.

50 Ward - Trobisch, Bringing the Word, 15. 
Brown, R.E., The Birth of the Messiah. A Commentary on the Infancy Narratives in the Gospels of Matthew and Luke, 2 ed. (Anchor Bible Reference Library; New York: Doubleday 1993).

Carter, W., "Zechariah and the Benedictus (Luke 1:68-79): Practicing What He Preaches," Biblica 69 (1988) 239-247.

Dillon R.J., "The Benedictus in Micro- and Macrocontext," Catholic Biblical Quarterly 68 (2006) $457-480$.

Dodson, J.R., The 'Powers' of Personification. Rhetorical Purpose in the 'Book of Wisdom' and the Letter to the Romans (Beihefte zur Zeitschrift für die neutestamentliche Wissenschaft 161; Berlin: de Gruyter 2008).

Farris, S., The Hymns of Luke's Infancy Narratives. Their Origin, Meaning and Significance (Journal for the Study of the New Testament Supplement Series 9; Sheffield: Bloomsbury 1985).

Fitzmyer, J.A., The Gospel according to Luke I-IX. Introduction, Translation, and Notes (Anchor Bible 28; New Haven, CT - London: Yale University Press 2008).

Franke, W., "At the Creative Source of the Arts: Poetry as Prophecy in a Negative Theological Key," Prophetic Witness and the Reimagining of the World. Poetry, Theology and Philosophy in DialoguePower of the Word V (eds. M.S. Burrows - H. Davies - J. von Zitzewitz) (Routledge Studies in Religion; New York: Routledge 2021) 26-56.

Geldenhuys, N., Commentary on the Gospel of Luke. The English Text with Introduction, Exposition and Notes (New International Commentary on the New Testament; Grand Rapids, MI: Eerdmans 1952).

Geller, S.A. "Were the Prophets Poets?" Prooftexts: A Journal of Jewish Literary History 3 (1983) 211-221.

Gera, D.L., Ancient Greek Ideas on Speech, Language, and Civilization (New York: Oxford University Press 2003).

Harris, W.V., Ancient Literacy (Cambridge: Harvard University Press 1989).

Heath, J., The Talking Greeks. Speech, Animals, and the Other in Homer, Aeschylus, and Plato (New York: Cambridge University Press 2005).

Heffelfinger, K.M., I Am Large, I Contain Multitudes. Lyric Cohesion and Conflict in Second Isaiah (Leiden: Brill 2011).

Heffelfinger, K.M., "More than Mere Ornamentation," Proceedings of the Irish Biblical Association 36 (2013) 36-54.

Hezser, C., Jewish Literacy in Roman Palestine (Texte und Studien zum antiken Judentum 81; Tübingen: Mohr Siebeck 2001).

Holland, G.S., "Paul and Performance," Paul in the Greco-Roman World. A Handbook (ed. J.P. Sampley) (London: Bloomsbury 2016) II, 239-269.

Le Feuvre, C., "Language of Gods, Pythian Apollo and Plato's Cratylus," When Gods Speak to Men. Divine Speech according to Textual Sources in the Ancient Mediterranean Basin (eds. S. Anthonioz - A. Mouton - D. Petit) (Orbis biblicus et orientalis 289; Leuven: Peeters 2019) 81-104.

McNicol, A.J., "Rebuilding the House of David: The Function of the Benedictus in Luke-Acts," Restoration Quarterly 40 (1998) 25-38.

Mendez, H.E., Canticles in Translation. The Treatment of Poetic Language in the Greek, Gothic, Classical Armenian, and Old Church Slavonic Gospels (Diss. The University of Georgia; Athens 2013).

Murray, P., "Poetic Inspiration," Companion to Ancient Aesthetics (eds. P. Destrée - P. Murray) (Chichester: Wiley \& Sons 2015) 158-174. 
Newman Jr., B.M., A Concise Greek-English Dictionary of the New Testament (Stuttgart: Deutsche Bibelgesellschaft - United Bible Societies 1993).

Nolland J., Luke 1:1-9:20 (Word Biblical Commentary 35A; Dallas, TX: Word 1989).

Perelman, C. - Olbrechts-Tyteca, L., The New Rhetoric. A Treatise on Argumentation (Notre Dame, IN: University of Notre Dame Press 1969; 1973).

Plato, Cratylus. Parmenides. Greater Hippias. Lesser Hippias (trans. H.N. Fowler) (Loeb Classical Library 167; Cambridge, MA: Harvard University Press 1926).

Plato, Euthyphro. Apology. Crito. Phaedo (trans. E. Jones - W. Preddy) (Loeb Classical Library 36; Cambridge, MA: Harvard University Press 2017).

Plato, Statesman. Philebus. Ion (trans. H.N. Fowler - W.R.M. Lamb) (Loeb Classical Library 164; Cambridge, MA: Harvard University Press 1925).

Porter, S.E. - Pitts, A.W., Fundamentals of New Testament Textual Criticism (Grand Rapids, MI: Eerdmans 2015).

Ringgren, H., "Luke's Use of the Old Testament," Harvard Theological Review 79 (1986) 227-235.

Stanley, C.D., "Paul and Homer: Greco-Roman Citation Practice in the First Century," Novum Testamentum 32 (1990) 48-78.

Tannehill, R.C., The Narrative Unity of Luke-Acts. A Literary Interpretation. I. The Gospel According to Luke (Minneapolis, MN: Fortress 1991).

Ward, R.F. - Trobisch, D., Bringing the Word to Life. Engaging the New Testament through Performing It (Grand Rapids, MI: Eerdmans 2013).

Wierzbicka, A., "The Semantics of Direct and Indirect Discourse," Papers in Linguistics 7 (1974) 267-307.

Winsbury, R., The Roman Book. Books, Publishing and Performance in Classical Rome (London: Duckworth 2009).

Wright, B.J., Communal Reading in the Time of Jesus. A Window into Early Christian Reading Practices (Minneapolis, MN: Fortress 2017). 